\title{
RELATIONSHIP BETWEEN PLASMA CREATININE CONCENTRATION AND GLOMERULAR FILTRATION IN PRETERM NEWBORN INFANTS
}

\author{
Mário Cícero Falcão, Yassuhiko Okay and José Lauro Araújo Ramos
}

RHCFAP/2975

FALCÃO, M. C. et al. - Relationship between plasma creatinine concentration and glomerular filtration in preterm newborn infants. Rev. Hosp. Clín.

Fac. Med. S. Paulo 54 4: 121 - 126,1999.

SUMMARY: Fluid management and dosage regimens of drugs in preterm infants should be based on the glomerular filtration rate. The current methods to determine glomerular flitration rate are invasive, time-consuming, and expensive. In contrast, creatinine clearance can be easy obtained and quickly determined. The purpose of this study was to compare plasma creatinine on the third and seventh day of life in preterm newborn infants, to evaluate the influence of maternal creatinine, and to demonstrate creatinine clearance can be used as a reliable indicator of glomerular filtration rate. We developed a prospective study (1994) including 40 preterm newborns (gestational age $<37$ weeks), average $=34$ weeks; birth weight (average) $=1840$ $\mathrm{g}$, in the first week of life. Inclusion criteria consisted of: absence of renal and urinary tract anomalies; $\mathrm{O}_{2}$ saturation $92 \%$; adequate urine output $(>1 \mathrm{ml} / \mathrm{kg} / \mathrm{hr})$; normal blood pressure; absence of infections and no sympathomimetic amines in use. A blood sample was collected to determine plasma creatinine (enzymatic method) on the third and seventh day of life and creatinine clearance $(\mathrm{CrCl})$ was obtained using the following equation: $\mathrm{CrCl}(\mathrm{ml} / \mathrm{min} / 1.73 \mathrm{~m} 2)=\ldots$ K x length $(\mathrm{cm}), \mathrm{k}=0.33$ in preterm infant Plasma creatinine $(\mathrm{mg} / \mathrm{dl}) \mathrm{C}$

All plasma creatinine determinations showed normal values [third day: $0.78 \mathrm{mg} / \mathrm{dl} \pm 0.24(\mathrm{mean} \pm \mathrm{SD}$ ) and seventh day: $0.67 \mathrm{mg} / \mathrm{dl} \pm 0.31-$ $(\mathrm{p}>0.05)$ ]. Also all creatinine clearance at third and seventh day of life were normal [third day: $19.5 \mathrm{ml} / \mathrm{min} \pm 5.2$ (mean \pm SD) and seventh day: 23.8 $\mathrm{ml} / \mathrm{min} \pm 7.3-(\mathrm{p}>0,05)]$. All preterm infants developed adequate renal function for their respective gestational age. In summary, our results indicate that, for clinical practice, the creatinine clearance, using newborn length, can be used to estimate glomerular filtration rate in preterm newborn infants.

DESCRIPTORS: Creatinine. Creatinine clearance. Glomerular filtration rate.

Fluid management as well as dosage regimens of drugs in preterm newborn infants should be based on the glomerular filtration rate ${ }^{4}$. The measurement of glomerular filtration rate provides to the clinician an overall estimate of renal function ${ }^{1}$. Classic techniques for measuring glomerular filtration require the infusion of substances that are free filtered and are not reabsorbed, secreted, or metabolized by the kidney ${ }^{6}$. Agents used are inulin, 99mTc-DTPA, I-iothalamate, 51Cr-EDTA, and polyfructisan ${ }^{21}$.

The determination of inulin clearance is laborius, time-consuming, and is subject to inaccuracies due to the difficulty in obtaining 24 hour urine samples from newborn infants ${ }^{16}$. Few laboratories are equiped to measure inulin, and many clinicians are reluctant to expose their patients to radioactive markers ${ }^{20}$. An expedient method is to measure the clearance of endogenous creatine from a single plasma value, because the creatinine clearance approximates glomerular filtration rate, especially when the kidney function is within the normal range ${ }^{23}$.

Creatine is important in muscle metabolism and is synthesized in a two-step process involving the synthesis of glycocyamine ${ }^{22}$. Creatinine is

From Santa Catarina Hospital (São Paulo) Nursery Children's Institute, Clinical Hospital University of São Paulo, Medical School - São Paulo, SP - Brazil. formed as a result of nonenzymatic dehydration of muscle creatine. Consequently, creatinine formation has a direct relationship to muscle mass $^{22}$. Creatinine is free filtered by the glomeruli, but is not reabsorbed to any appreciable extent under normal circumstances ${ }^{19}$. However, tubular reabsorption of creatinine has been observed under certain clinical conditions, including congestive cardiac failure and uncontrolled diabetes mellitus $^{22}$. Tubular creatinine secretion may be inhibited by drugs, such as cimetidine, probenecid, and trimethropin ${ }^{16}$. Severe exercise and a high-protein diet can cause increased creatinine excretion ${ }^{16}$.

In summary, creatinine clearance is often interpreted as a measure of 
glomerular filtration rate and is used as an index of renal function in children and adults, but this relationship is not clear in early neonatal period because of the load of exogenous (maternal) creatinine.

In the light of these facts, the purpose of this study was to compare plasma creatinine on the third and seventh day of life in preterm newborn infants, focusing the evaluation of the influence of maternal creatinine, and to demonstrate that creatinine clearance can be used as a reliable indicator of glomerular filtration rate.

\section{PATIENTS AND METHODS}

The present study is part of a large protocol where we studied glycemiaglycosuria relationship in preterm newborn infants (with adequate renal function, based on normal plasma creatinine and absence of fetal and neonatal clinical alterations) ${ }^{7}$. This prospective study was developed in Neonatal Intensive Care Unit of Santa Catarina Maternity Hospital (São Paulo, Brazil), a private hospital which attends middle-class mothers. The protocol was approved by the Ethics Committee and all newborns were included after consent from their parents.

From January 1- to December 31,
1994, 40 preterm newborn infants were studied, selected through routine tracking in the Nursery, in the first week of life. Prematurity was defined as a gestational age of less than 37 weeks after the date of the mother's last menstruation. In the absence of this information, ultrasonographic evaluation and also the Dubowitz Method were used. The preterm newborns were classified by size as small, adequate, or large, according to a birth curve adopted by the Service. In this population plasma creatinine was determined on the third and seventh day of life.

Inclusion criteria consisted of: absence of renal and urinary tract anomalies; satisfactory hemodynamics and respiration (O2 saturation $92 \%$ measured by pulse oximeter); adequate urine output $(>1 \mathrm{ml} / \mathrm{kg} / \mathrm{hr})$; mean blood pressure $45-60 \mathrm{mmHg}$; absence of infections and no sympathomimetic amines in use.

Blood samples were collected from the veins of hand dorsal $\operatorname{arc}^{10}$. Blood sample volume was $1 \mathrm{cc}$ for each determination.

Creatinine determinations were based on enzyme reactions ${ }^{16}$. This procedure used with the Ektachen analyzer is based on the enzymatic reaction of creatinine with creatinine imidohydrolase to form N-methylhidantoin and ammonium ion. It is measured by reflectance spectrophotometry. Interfering substances for this reaction include glucose, 5-flucytosine, and environmental ammonia ${ }^{13}$.

Blood samples were collected with proper techniques, avoiding hemoly$\mathrm{sis}^{22}$. Determinations were performed within 30-minute sampling because of creatinine lability ${ }^{22}$.

Creatinine clearence $(\mathrm{CrCl})$ was obtained by the following equation: ${ }^{16}$ $\mathrm{CrCl}\left(\mathrm{ml} / \mathrm{min} / 1.73 \mathrm{~m}^{2}\right)=\underline{\mathrm{K} x \text { length }(\mathrm{cm})}$ $\mathrm{P}_{\mathrm{Cr}}(\mathrm{mg} / \mathrm{dl})$

$\mathrm{k}=0.33$ in preterm infants;

$\mathrm{CrCl}$ : creatinine clearance;

$P_{\text {Cr: }}$ plasma creatinine.

Length was obtained by an anthropometer (scale in millimeters) and all measurements was repeated to confirm results.

After creatinine clearance calculation, comparison between third and seventh day of life data were done.

The $t$ test was used for mean comparison. In all cases, statistical significance was estimated at a $p$ value $<0.05$.

\section{RESULTS}

The population for the study comprised 40 preterm newborn infants. Background factors are listed in table 1 .

Plasma creatinine determinations on the third and seventh day of life

Table 1 - Characteristics of the study population.

\begin{tabular}{l|l|c|c}
\hline Variables & \multicolumn{2}{c}{ n (40) } & $(\%)$ \\
\hline Sex & Male & 23 & $(57.5)$ \\
Classification & Female & $17.5)$ & $(70.0)$ \\
& AGA & 28 & $(30.0)$ \\
BW (g) & SGA & 12 & $(7,5)$ \\
& $\leq 999$ & 3 & $(7.5)$ \\
& $1000-1499$ & 3 & $(35,0)$ \\
Length (cm) & $1500-1999$ & 14 & $(50.0)$ \\
Head circumference (cm) & $2000-2499$ & 20 & $(12,5)$ \\
GA (wk) & Average & 1846.5 & $(32.5)$ \\
& Average & 40.9 & $(55.0)$ \\
\hline
\end{tabular}

AGA: adequate for gestational age; SGA: small for gestational age; BW: birth weight;

GA: gestational age 
(Table 2) were:

- third day: $0.78 \mathrm{mg} / \mathrm{dl} \pm 0.24$ (mean $\pm \mathrm{SD}$ ), CI95\% -0.68 to 0.96 , variation - 0.5 to $1.0 \mathrm{mg} / \mathrm{dl}$;

- seventh day: $0.67 \mathrm{mg} / \mathrm{dl} \pm 0.31$ (mean $\pm \mathrm{SD}$ ), CI95\% -0.42 to 0.89 , variation - 0.3 to $0.9 \mathrm{mg} / \mathrm{dl}$;

There was no statistically significant difference between mean plasma creatinine determinations on the third and seventh day of life.

All plasma creatinine levels were within the normal range for the neonatal period $\left(0.3\right.$ to $\left.1.0 \mathrm{mg} / \mathrm{dl}^{14}\right)$.

Creatinine clearance rates, obtained by newborn length on the third and seventh day of life (Table 3), were:

- third day: $19.5 \mathrm{ml} / \mathrm{min} \pm 5.2$ (mean $\pm \mathrm{SD}$ ), CI95\% -16.6 to 23.5 , variation - 16.0 to $32.0 \mathrm{ml} / \mathrm{min}$;

- seventh day: $23.8 \mathrm{ml} / \mathrm{min} \pm 7.3$ (mean $\pm \mathrm{SD}$ ), CI95\% - 17.9 to 38.0 , variation -17.7 to $53.3 \mathrm{ml} / \mathrm{min}$.

All creatinine clearance rates on the third and seventh day of life were within low and upper limits, minimum acceptable is $10 \mathrm{ml} / \mathrm{min}^{14}$. There was no statistically significant difference between creatinine clearance rates on the third and seventh day of life.

All 40 preterm newborn infants that participated in this study developed adequate renal function for their respective gestational age.

\section{DISCUSSION}

Table 2 - Variations of plasma creatinine on the third and seventh day of life.

\begin{tabular}{|c|c|c|}
\hline & $\begin{array}{l}\text { Plasma creatinine } \\
\text { third day }\end{array}$ & $\begin{array}{l}(\mathrm{mg} / \mathrm{dl}) \\
\text { seventh day }\end{array}$ \\
\hline $\begin{array}{l}\text { Average } \\
\text { CI } 95 \% \\
\text { Variation }\end{array}$ & $\begin{array}{l}0.78^{*} \\
0.68-0.96 \\
0.5 \text { to } 1.0\end{array}$ & $\begin{array}{l}0.67^{*} \\
0.42-0.89 \\
0.3 \text { to } 0.9\end{array}$ \\
\hline
\end{tabular}

${ }^{*} \mathrm{p}>0.05 ; \mathrm{CI}$ - confidence interval

Table 3 - Variations of creatinine clearance rates on the third and seventh day of life.

\begin{tabular}{l|l|l}
\hline & $\begin{array}{l}\text { Creatinine clearance } \\
\text { third day }\end{array}$ & $\begin{array}{l}\text { (ml/min) } \\
\text { seventh day }\end{array}$ \\
\hline Average & $19.5^{*}$ & $23.8^{*}$ \\
CI 95\% & $16.6-23.5$ & $17.9-38.0$ \\
Variation & 16.0 to 32.0 & 17.7 to 53.3 \\
\hline
\end{tabular}

${ }^{*} \mathrm{p}>0.05 ; \mathrm{CI}$ - confidence interval
Transition from fetal to postnatal life requires an important renal participation $^{3}$. This participation includes fluids, electrolytes, and nitrogen excretion. Int fetal life, the placenta can provide this function ${ }^{2}$. The neonatal kidney is able to perform this function, although it shows some immaturity. However, this balance can be disrupted, mainly in preterm newborn infants, because the capacity of the kidney to clear certain drugs is dependent to a great extent on the total amount of filtered fluid, and the higher body weight, the higher the glomerular filtration rate will be 9 .

The determination of inulin clearance is laborious, time-consuming, and expensive. For this reason, radiolabeled compounds have been used, but clinicians are reluctant to administer these compunds, particularly to neonate ${ }^{16}$. For these reasons, the clearance of creatine, a small molecular weight substance that exists naturally in the blood and urine and can be measured easily, has become a widely used method for estimating glomerular filtration rate in clinical practice ${ }^{17}$. However, creatinine clearance may deviate from inulin clearance, for example, due to changes in dietary protein intake or metabolic state ${ }^{6}$. Small errors in the measurement of plasma creatinine may lead to errors in the estimation of glomerular filtration rate ${ }^{22}$. In addition, creatinine is not only filtered through glomeruli, but is also secreted by renal tubule, resulting in overestimating glomerular filtration rate. Despite these limitations, creatinine clearance remains the most practically useful method for estimating glomerular filtration rate ${ }^{16}$.

Production of urine by the fetus is important in the formation of amniotic fluid (essential for normal development of lungs $)^{5}$. Glomerular filtration rate remains constant throughout gestation, but 24 hours after delivery, the glomerular filtration rate triples, with increase of kidney flow and mass. This increase is directly proportional to maturity of the infant, but other variables must be considered ${ }^{15}$.

Several methods are available for the measurement of plasma creatinine. The Jaffe technique, based on colorimetric reaction, has low specificity because the reagent reacts with many interfering substances ${ }^{12}$. Recently, enzymatic techniques have become reliable to be used routinely. The most commonly used enzymatic methods include the amidohydrolasecreatinine kinase-pyruvate, kinaselactate dehydrogenase technique, the creatinine-creatinase-sarcosinoxidase-peroxidade technique and the iminohydrolase technique. They provide an excellent sensibility and specificity $^{22}$.

All plasma creatinine determination in our study were performed using the enzymatic method (creatinine imidohydrolase), in order to exclude interferences of some substances, such as glucose, bilirubin, antibiotics (cephalosporins), and ketone bodies, because these chromogens components could increase plasma creatinine results ${ }^{8}$.

The complex relationship between plasma creatinine and glomerular filtration rate during growth led to the development of the formulas for estimating glomerular filtration using some parameter of body size ${ }^{18}$. Using body length, Schwartz et al. (1987) derived a formula that correlates very closely with those obtained from crea- 
tinine and inulin clearance, where $\mathrm{k}$ was obtained by regression analysis. The value of $\mathrm{k}$ for preterm newborn infants is 0.33 ( 0.31 to 0.34$)$; when malnutrition is present, $\mathrm{k}$ tends to be lower ${ }^{16}$.

In the first days of life, newborn and her mother have similar levels of plasma creatinine. After that, newborn levels decrease until $0.4 \mathrm{mg} / \mathrm{dl}$ (second week of life $)^{1 .}$ In preterm newborns, after 34 weeks, plasma creatinine levels quickly drop, showing a complete nephrogenesis ${ }^{2}$.

In this study, we emphasized that the selected newborn infants showed absence of renal and urinary tract anomalies, satisfactory hemodynamics and respiration (O2 saturation $92 \%$ measured by pulse oximeter), adequate urine output $(>1 \mathrm{ml} / \mathrm{kg} / \mathrm{hr}$ ), systolic and diastolic blood pressure above the third percentile adjusted for gestational age, and absence of infections; also they had never received drugs that could possibly have influenced the glomerular filtration rate (aminoglycosides, antiepileptic drugs, theophylline, dobutamine, dopamine, indomethacin, midazolan), in order to exclude some factors that could interfere on our results ${ }^{20}$.

In addition, plasma determinations were preferred over whole blood for measuring creatinine, because consi- derable amounts of noncreatinine chromogens are present in the erythrocytes. Although hemolysis does not affect the determination of creatinine, it increases the creatine value by $100 \%$ to $200 \%$. Also, all determinations were performed within $30 \mathrm{~min}$ utes after the collection ${ }^{22}$.

In full-term newborn infants, maternal and neonate creatinine levels are similar in the first week of life ${ }^{17}$. However, in preterm newborns, the time of influence of the maternal contribution remains unclear, because renal maturity and chronological age are important factors in improved glomerular filtration rate.

In the present study, there was no statistically significant difference between mean plasma creatinine determinations on the third and seventh day of life. These findings support the conclusion that maternal creatinine levels have no influence during first week of life, at least after the second day. Also, all plasma creatinine levels were normal for the neonatal period, defined as 0.3 to $1.0 \mathrm{mg} / \mathrm{dl}$.

In addition, all creatinine clearance rates, obtained using newborn length on the third and seventh day of life, were in normal range. These results suggest that our newborn infants had an adequate glomerular filtration rate, in accordance with Howard and Spitzer ${ }^{9}$ (1992). These authors demonstrated that the creatinine clearance is $15.3+5.6 \mathrm{ml} / \mathrm{min}$ in neonates with gestational age between 29 and 37 weeks $^{9}$.

Exact correlations between plasma creatinine levels and different gestational ages remain difficult to analyze, because many variables must be considered, such as maternal renal function, hydration and catabolic status, and increase in muscle mass (per unit of body size) ${ }^{16}$. In view of these facts, an isolated creatinine determination cannot reveal the glomerular filtration status. Periodic plasma creatinine determinations are indicated to better evaluate the glomerular filtration rate.

In summary, our analysis showed that the period of maternal plasma creatinine influence could be less than one week of life. However, further investigation in preterm newborn infants with different gestational ages might be helpful to confirm our results. Also, the results of our study suggest that, for clinical practice, creatinine clearance, using newborn length, can be accepted as a useful measure of glomerular filtration rate in neonatal period. Also, it could be used to evaluate whether kidney function is within or outside the normal range for the peculiar gestational age, and whether further adjustments of dosing and fluid management are needed.
FALCÃO, M. C. e col. - Creatinina sanguínea em recém-nascido prétermo e sua relação com a filtração glomerular. Rev. Hosp. Clín. Fac. Med. S. Paulo 54 (4): 121 126, 1999.

Na prática neonatal é importante a verificação da função de filtração glomerular para que o manuseio de recém-nascidos pré-termo seja facilitado. Métodos específicos são demorados, tecnicamente difíceis, invasivos e dispendiosos. Para tal, métodos simples e eficazes são benvindos. A determinação do clearance de creatinina se encaixa facilmente nestes que- sitos. Esta pesquisa teve como objetivo comparar os níveis de creatinina sanguínea no $3^{\circ}$ e $7^{\circ}$ dias de vida em recém-nascido pré-termo, com o intuito de se mostrar a validade do clearence de creatinina sanguínea como avaliação da função de filtração glomerular renal no período neonatal. 
Foi realizado um estudo prospectivo durante o ano de 1994, onde foram selecionados 40 recém-nascidos pré-termo (idade gestacional $<37$ semanas), média de $34 \mathrm{sem}-$ anas, peso de nascimento médio de $1840 \mathrm{~g}$, na $1^{\mathrm{a}}$ semana de vida. Os critérios de inclusão foram: ausência de malformações nefro-urológicas, hemidinâmica estável, diurese $>1 \mathrm{ml} / \mathrm{h}$, pressão arterial média normal, saturação de $\mathrm{O}_{2} 92 \%$, ausência de infecções e sem drogas vasoativas.
Foram realizadas as determinações da creatinina sanguínea no $3^{\circ}$ e $7^{\circ}$ dias (método enzimático) e calculados seus respectivos clearances (CCR) através da fórmula*

As determinações de creatinina situaram-se dentro da faixa de normalidade [ $3^{\circ}$ dia: média: $0,78 \mathrm{mg} / \mathrm{dl}+0,24$ e $7^{\circ}$ dia: média: $0,67 \mathrm{mg} / \mathrm{dl}+0,31$, $(p>0,05)]$ e também de seus respectivos clearances $\left[3^{\circ}\right.$ dia: média: $19,5 \mathrm{ml} / \mathrm{min}+5,2$ e $7^{\circ}$ dia: média: $23,8 \mathrm{ml} / \mathrm{min}+7,3,(\mathrm{p}>0,05)]$. Todos os *CCR $(\mathrm{ml} / \mathrm{min} / 1,73 \mathrm{~m} 2)=\frac{\mathrm{K} \times \text { comprimento }(\mathrm{cm})}{\text { creatina sanguínea }(\mathrm{mg} / \mathrm{dl})}$ $\mathrm{k}=0,33$ para o RNPT.
$\mathrm{RN}$ evoluíram sem alteração clínica aparente da função renal. Concluindose, os resultados deste estudo, quanto à determinação do clearance de creatinina através do cálculo pelo comprimento do recém-nascido, apoiam o emprego deste para uma avaliação aceitável da função de filtração glomerular no período neonatal.

\section{DESCRITORES: Creatinina.}

\section{Clearance de creatinina. Taxa de fil-}

tração glomerular. Recém-nascido

\section{REFERENCES}

01. APERIA A, BROBERGER O \& ELINDER G - Postnatal development of renal function in preterm and full-term infants. Acta Pediatr Scand 1981; 70:183-7.

02. ARANT Jr B S - Estimating glomerular filtration rate in infants. $\mathbf{J}$ Pediatr 1984; 104:890-3.

03. ARANT Jr B S - Neonatal adjustment to extrauterine life. In: Edelmann Jr CM, eds. Pediatric kidney disease. 2nd ed. Boston, Little, 1992 p. 1015-42.

04. AVILES D H, FILDES R D \& JOSE P A - Evaluation of renal function. Clin Perinatol 1992; 19:69-84.

05. BRION L P, SATLIN L M \& EDELMANN Jr C M - Renal disease. In: AVERY G B, FLETCHER M A \& MACDONALD M G, eds. - Neonatology: pathophysiology and management of the newborn. Philadelphia, Lippincott, 1994. p. 792-886.

06. COULTHARD M G - Comparison of methods of measuring renal function in preterm babies using inulin. J Pediatr 1983; 12:159-61.

07. FALCÃO M C - Efeitos da infusão parenteral de glicose sobre glicemia e glicosúria em recém-nascidos pré-termo saudáveis e doentes. São Paulo, 1996. (Tese Doutorado) - Faculdade de Medicina da Universidade de São Paulo.

08. FELD L C, LANGFORD D J \& SCHWARTZ G J - The effect of neonatal hyperbilirubinemia on the measurement of plasma creatinine. Clin Pediatr 1984; 23:154-56.

09. HOWARD E C \& SPITZER A - Renal blood flow and glomerular filtration rate during development. In: EDELMANN Jr C M, eds. Pediatric kidney disease. $2^{\text {nd }}$ ed. Boston, Little, 1992. p. 49-78.
10. HUGHES W T \& BUESCHER E S - Pediatric procedures. $2^{\text {nd }} e d$. Philadelphia, Saunders, 1980 p. 55-87.

11. INGELFINGER Jr - Renal conditions in the newborn period. In: CLOHERTY J P \& STARK AR, eds. - Manual of neonatal care. $2^{\text {nd }}$ ed. Boston, Little, 1991. p. 477-95.

12. KIM M S \& EMMA F - Renal conditions. In: CLOHERTY J P \& STARK AR, eds. - Manual of neonatal care. $4^{\text {th }}$ ed. Philadelphia, Lippincott 1998. p. 591-607.

13. MOSS G A, BONDAR R J L \& BUZZELLI D M - Kinetic enzymatic method for determining serum creatinine. Clin Chem 1985; 21:1422-26.

14. RUDD P T \& HUGHES E A - Reference ranges for plasma creatinine during the first month of life. Arch Dis Child 1983; 58:212-15.

15. SCHAFFER S E \& NORMAN ME - Renal function and renal failure in the newborn. Clin Perinatol 1989; 16:199-218.

16. SCHWARTZ G J, BRION L P \& SPITZER A - The use of plasma creatinine concentratrion for estimating glomerular filtration rate in infants, children, and adolescents. Pediatr Clin N Am 1987; 34:571-90.

17. SCHWARTZ G J, FELD L G \& LANGFORD D J - A simple estimate of glomerular filtration rate in full-term infants during the first year of life. J Pediatr 1984; 104:849-54.

18. SUTPHEN J L - Anthropometric determinants of creatinine excretion in preterm infants. Pediatrics 1982; 69:719-23. 
19. TULASSAY T, RITVAY J, BORS Z et al. - Alteration in creatinine clearance during respiratory distress syndrome. Biol Neonate 1979; 35:258-63.

20. VAN DER ANKER J N, GROOT R, BROERSE H M et al. Assessment of glomerular filtration rate in preterm infants by serum creatinine: comparison with inulin clearance. Pediatrics 1995; 96:1156-8.

21. WILKINS B H - A reappraisal of the measurement of glomerular filtration rate in preterm infants. Pediatr Nephrol 1992; 6:323-27.
22. WOO J \& CANNON D C - Metabolic and inorganic ions. In: HENRY J B, ed. Clinical diagnosis ans management by laboratory methods. $18^{\text {th }}$ ed. Philadelphia, Saunders, 1991. p. 140-71.

23. ZACHELLO G, BONDIO M \& SAIA O S - Simple estimate of creatinine clearance from plasma creatinine in neonates. Arch Dis Child 1982; 57:297-300.

Received for publication on the 02/08/99 